\title{
School Literacy Movement, Scientific Literacy, and Science Matter Inventory for Hearing Impaired Students
}

\author{
Sri Poedjiastoeti \\ Department of Chemistry \\ Universitas Negeri Surabaya \\ Surabaya, Indonesia \\ sripoedjiastoeti@unesa.ac.id
}

\author{
Wagino \\ Department of Special Education \\ Universitas Negeri Surabaya \\ Surabaya, Indonesia
}

\author{
Dian Avina Turja Soffa \\ Science Education, Postgraduate Program \\ Universitas Negeri Surabaya \\ Surabaya, Indonesia
}

\begin{abstract}
This paper aims to describe results of inventory school literacy movement (SLM), scientific literacy, and science matter in school for dissabilities especially hearing impairment students. This results used to design science multimedia was appropriate with hearing impairment students, especially for elementary school for dissabilities. The design used to basic of developing and producing, so can provided utilities that needed for scientific literacy activity as supporting SLM. The inventory data obtained through direct observation and assessment sheets of SLM, science literacy, and science matter, and then analyzed descriptively. Based on the inventory results there are components has not been maximized, so it needs active roles from various parties to completed the utilities in scientific literacy activity in school for dissabilities hearing impairment.
\end{abstract}

Keywords - literacy, SLM, science literacy, science matter, school for dissabilities, hearing impairment.

\section{INTRODUCTION}

School Literacy Movement (SLM), is one part of National Literacy Movement (NLM) which began to be developed nationally starting in 2015. NLM is one of government's efforts through the Ministry of Education and Culture to eradicate literacy and improve the ability human resources. These abilities must be balanced with the ability to think critically, solve problems, be creative, be communicative, and collaborative [1].

SLM is specialized in school by involving students, education staff, and parents. SLM helps students to master the six basic literacy namely language literacy, numeracy, science, digital, finance, as well as culture and citizenship. The SLM program can be integrated in teaching and learning activities. The success of literacy needs to be pursued through activities that foster a culture literacy that is adapted to school culture [1].

Basically students in school for dissabilities must develop language skills which include listening, speaking, reading and writing skills. These four skills are found in every learning activity and are adjusted to the obstacles students have. [2]

Scientific literacy is one of base literacy which students must master through SLM. Scientific literacy is the one of important objective of science education. Scientific literacy describe the ability of students to understand scientific laws, theories, phenomena, and things. Scientific literacy focus on students skills to use scientific knowledge in real situations [3].

Scientific literacy is specifically for students with hearing impairment. Physically, someone who has a special need for hearing impairment is no different from a normal person. In hearing impairment students, all information in learning and everyday life that is auditive must be visualized [4].

Utility and infrastructure as well as learning activities need to be considered so that the implementation of scientific literacy can run well. Obstacle to hearing impaired students can be overcome by having the right science (chemistry) learning device. The learning device must optimize the function of the other senses [5]. Therefore, there is a need for interactive multimedia (IMM) science that is adapted to hearing impairment students as a support for scientific literacy.

Some research on hearing impairment student learning, especially in science began in 2007 about the introduction of basic tools and skills in science experiment [6]. Subsequent research on learning science for hearing impairment students [4]. Development of IMM for Senior High School for Dissabilities (SHSD) and Junior High School for Dissabilities (JHSD) with the topic of chemistry in everyday life and elements, compounds, mixtures [7][8][9]. 


\section{METHODS}

The instrument used was the assessment sheet for SLM, scientific literacy, and science matter. The assessment sheet for SLM refers to the Ministry of Education and Culture's NLM evaluation and evaluation guidelines [10]. The assessment sheets for scientific literacy are adjusted to the scientific literacy indicators [11]. The assessment sheet for science matter is adjusted to the material at the level Elementary School for Dissabilities (ESD).

Each component in the assessment sheet has several success indicators assessed. The value given is adjusted to the criteria score of $0-4$ on each success indicator. The data obtained were recapitulated and analyzed descriptively to obtain initial information about SLM, scientific literacy, and science matter at school for dissabilities.

\section{RESULTS AND DISCUSSION}

\section{A. Results}

This research conducted on 4 different school for dissabilitiess namely Pertiwi Mojokerto school for dissabilities, Kemala Bhayangkari 2 Gresik school for dissabilities, State School for dissabilities of Pandaan, and State School for dissabilities of Gedangan. The inventory results of SLM, science literacy, and science matter are described as follows.

\section{School Literacy Movement Inventory}

SLM assessment conducted by headmaster. The inventory results are shown in Table I.

TABLE I. RESULTS OF SCHOOL LITERACY MOVEMENT INVENTORY

\begin{tabular}{|c|c|c|c|c|c|c|c|c|c|c|c|c|c|}
\hline \multirow{3}{*}{ Component } & \multirow{3}{*}{ SI } & \multicolumn{12}{|c|}{ Score } \\
\hline & & \multicolumn{3}{|c|}{ MJK } & \multicolumn{3}{|c|}{ GRS } & \multicolumn{3}{|c|}{$P D N$} & \multicolumn{3}{|c|}{$G D G$} \\
\hline & & $E$ & $J$ & $S$ & $E$ & $\boldsymbol{J}$ & $S$ & $\boldsymbol{E}$ & $\boldsymbol{J}$ & $S$ & $\boldsymbol{E}$ & $\boldsymbol{J}$ & $S$ \\
\hline \multirow{4}{*}{$\begin{array}{l}\text { 1. Initial } \\
\text { assess- } \\
\text { ment }\end{array}$} & $\mathrm{A}$ & 4 & 3 & 3 & 1 & 1 & 1 & 3 & 3 & 3 & 2 & 3 & 3 \\
\hline & $\mathrm{B}$ & 3 & 3 & 3 & 1 & 1 & 1 & 3 & 3 & 3 & 2 & 2 & 2 \\
\hline & $\mathrm{C}$ & 3 & 3 & 3 & 4 & 4 & 4 & 2 & 2 & 2 & 3 & 3 & 3 \\
\hline & $\mathrm{D}$ & 3 & 3 & 3 & 1 & 1 & 1 & 2 & 2 & 2 & 2 & 2 & 2 \\
\hline \multirow{2}{*}{$\begin{array}{ll}\text { 2. } & \text { SLM } \\
\text { Sociali- } \\
\text { zation }\end{array}$} & $\mathrm{A}$ & 2 & 2 & 2 & 1 & 1 & 1 & 4 & 4 & 4 & 3 & 3 & 3 \\
\hline & B & 2 & 2 & 2 & 2 & 2 & 2 & 3 & 3 & 3 & 2 & 2 & 2 \\
\hline \multirow{2}{*}{$\begin{array}{l}\text { 3. SLM } \\
\text { Policy } \\
\text { Design }\end{array}$} & $\mathrm{A}$ & 0 & 0 & 0 & 0 & 0 & 0 & 2 & 2 & 2 & 2 & 2 & 2 \\
\hline & B & 2 & 2 & 2 & 3 & 3 & 3 & 2 & 2 & 2 & 2 & 2 & 2 \\
\hline \multirow{5}{*}{$\begin{array}{l}\text { 4. } \text { SLM } \\
\text { Activity } \\
\text { Design }\end{array}$} & $\mathrm{A}$ & 3 & 3 & 3 & 1 & 1 & 1 & 3 & 3 & 3 & 2 & 2 & 2 \\
\hline & B & 3 & 3 & 3 & 4 & 4 & 4 & 4 & 4 & 4 & 3 & 3 & 3 \\
\hline & $\mathrm{C}$ & 2 & 2 & 2 & 2 & 2 & 2 & 3 & 3 & 3 & 3 & 3 & 3 \\
\hline & D & 2 & 2 & 2 & 1 & 1 & 1 & 3 & 3 & 3 & 2 & 2 & 2 \\
\hline & $\mathrm{E}$ & 2 & 2 & 2 & 4 & 4 & 4 & 4 & 4 & 4 & 2 & 2 & 2 \\
\hline \multirow{4}{*}{$\begin{array}{l}\text { 5. } \\
\text { SLM } \\
\text { Develop- } \\
\text { ment } \\
\text { base on } \\
\text { learning }\end{array}$} & A & 2 & 2 & 2 & 1 & 1 & 1 & 4 & 4 & 4 & 3 & 3 & 3 \\
\hline & B & 3 & 3 & 3 & 4 & 4 & 4 & 3 & 3 & 3 & 2 & 2 & 2 \\
\hline & $\mathrm{C}$ & 2 & 2 & 2 & 1 & 1 & 1 & 2 & 2 & 2 & 2 & 2 & 2 \\
\hline & $\mathrm{D}$ & 2 & 2 & 2 & 4 & 4 & 4 & 3 & 3 & 3 & 3 & 3 & 3 \\
\hline \multirow{3}{*}{$\begin{array}{l}\text { 6. NLM } \\
\text { Develop- } \\
\text { ment }\end{array}$} & $\mathrm{A}$ & 2 & 2 & 2 & 1 & 1 & 1 & 3 & 3 & 3 & 3 & 3 & 3 \\
\hline & B & 1 & 1 & 1 & 2 & 2 & 2 & 2 & 2 & 2 & 3 & 3 & 3 \\
\hline & $\mathrm{C}$ & 1 & 1 & 1 & 1 & 1 & 1 & 0 & 0 & 0 & 3 & 3 & 3 \\
\hline
\end{tabular}

\begin{tabular}{|c|c|c|c|c|c|c|c|c|c|c|c|c|c|}
\hline \multirow{3}{*}{ Component } & \multirow{3}{*}{ SI } & \multicolumn{12}{|c|}{ Score } \\
\hline & & \multicolumn{3}{|c|}{ MJK } & \multicolumn{3}{|c|}{ GRS } & \multicolumn{3}{|c|}{ PDN } & \multicolumn{3}{|c|}{ GDG } \\
\hline & & $\boldsymbol{E}$ & $J$ & $S$ & $\boldsymbol{E}$ & $\boldsymbol{J}$ & $S$ & $\boldsymbol{E}$ & $J$ & $S$ & $\boldsymbol{E}$ & $\boldsymbol{J}$ & $S$ \\
\hline \multirow{7}{*}{$\begin{array}{l}\text { base on } \\
\text { School } \\
\text { Culture }\end{array}$} & D & 3 & 3 & 3 & 4 & 4 & 4 & 4 & 4 & 4 & 3 & 3 & 3 \\
\hline & E & 2 & 2 & 2 & 4 & 4 & 4 & 3 & 3 & 3 & 3 & 3 & 3 \\
\hline & $F$ & 2 & 2 & 2 & 2 & 2 & 2 & 3 & 3 & 3 & 3 & 3 & 3 \\
\hline & $G$ & 2 & 2 & 2 & 4 & 4 & 4 & 3 & 3 & 3 & 2 & 2 & 2 \\
\hline & $\mathrm{H}$ & 1 & 1 & 1 & 3 & 3 & 3 & 4 & 4 & 4 & 2 & 2 & 2 \\
\hline & I & 2 & 2 & 2 & 2 & 2 & 2 & 3 & 3 & 3 & 2 & 2 & 2 \\
\hline & $\mathrm{J}$ & 2 & 2 & 2 & 4 & 4 & 4 & 4 & 4 & 4 & 3 & 3 & 3 \\
\hline \multirow{5}{*}{$\begin{array}{l}\text { 7. SLM } \\
\text { Develop- } \\
\text { ment } \\
\text { base on } \\
\text { Society } \\
\end{array}$} & A & - & - & - & 4 & 4 & 4 & 1 & 1 & 1 & 2 & 2 & 2 \\
\hline & B & 1 & 1 & 1 & 4 & 4 & 4 & 3 & 3 & 3 & 2 & 2 & 2 \\
\hline & $\mathrm{C}$ & 2 & 2 & 2 & 4 & 4 & 4 & 2 & 2 & 2 & 2 & 2 & 2 \\
\hline & $\mathrm{D}$ & 2 & 2 & 2 & 2 & 2 & 2 & 2 & 2 & 2 & 1 & 1 & 1 \\
\hline & $E$ & 2 & 2 & 2 & 4 & 4 & 4 & 2 & 2 & 2 & 2 & 2 & 2 \\
\hline \multirow{6}{*}{$\begin{array}{l}\text { 8. Imple- } \\
\text { mentation } \\
\text { Six } \\
\text { Dimen- } \\
\text { tion of } \\
\text { Literacy }\end{array}$} & $\mathrm{A}$ & 3 & 3 & 3 & 2 & 2 & 2 & 2 & 2 & 2 & 3 & 3 & 3 \\
\hline & B & 3 & 3 & 3 & 0 & 0 & 0 & 2 & 2 & 2 & 1 & 1 & 1 \\
\hline & $\mathrm{C}$ & 3 & 3 & 3 & 2 & 2 & 2 & 2 & 2 & 2 & 2 & 2 & 2 \\
\hline & D & 0 & 0 & 0 & 1 & 1 & 1 & 2 & 2 & 2 & 2 & 3 & 3 \\
\hline & E & 1 & 1 & 1 & 1 & 1 & 1 & 3 & 3 & 3 & 2 & 2 & 2 \\
\hline & $\mathrm{F}$ & 3 & 3 & 3 & 1 & 1 & 1 & 3 & 3 & 3 & 3 & 3 & 3 \\
\hline \multirow{7}{*}{$\begin{array}{l}\text { 9. } \\
\text { SLM } \\
\text { Evalua- } \\
\text { tion }\end{array}$} & $\mathrm{A}$ & 0 & 0 & 0 & 0 & 0 & 0 & 2 & 2 & 2 & 1 & 1 & 1 \\
\hline & B & 1 & 1 & 1 & 2 & 2 & 2 & 2 & 2 & 2 & 2 & 2 & 2 \\
\hline & $\mathrm{C}$ & 0 & 0 & 0 & 1 & 1 & 1 & 2 & 2 & 2 & 1 & 1 & 1 \\
\hline & D & 2 & 2 & 2 & 2 & 2 & 2 & 4 & 4 & 4 & 2 & 2 & 2 \\
\hline & E & 1 & 1 & 1 & 1 & 1 & 1 & 2 & 2 & 2 & 2 & 2 & 2 \\
\hline & $\mathrm{F}$ & - & - & - & - & - & - & - & - & - & - & - & - \\
\hline & $\mathrm{G}$ & - & - & - & - & - & - & - & - & - & - & - & - \\
\hline
\end{tabular}

Annotation: SI : Success indicators, consists of several indicators that described in discussion; MJK : Pertiwi Mojokerto school for dissabilities; GRS : Kemala Bhayangkari 2 Gresik school for dissabilities; PDN : State School for dissabilities of Pandaan; GDG : State School for dissabilities of Gedangan; E : Elementary school; J : Junior high school; S : Senior high school.

Based on Table I, can be seen that the lowest value is 0 (zero) and the highest value is 4 (four). School with the lowest value (0) is MJK. School with the equal value in each component is GDG.

Every school has obstacles in implementing SLM. Barriers to GRS are the ability to interpret sentences. Ability to facilitate in several elements of SLM. The obstacle of PDN is the limited ability of students to cause literacy activities to be less than optimal. The obstacles of GDG occur in developing cooperation with the environment and society.

In addition, each school also provides advice to the Ministry of Education and Culture, local government and other parties. In general, suggestions for the Ministry of Education and Culture are the provision of facilities, in the form of books or other learning resources that fit the needs of students, and organizing training or workshops on GLS. Suggestions for local authorities, namely providing support for the implementation of GLS and organizing socialization related to GLS. Suggestions for other parties are to increase community participation and other parties to 
support SLM and to have periodic evaluations of SLM implementation. Every school hoping to get support from the government both the central government, the Ministry of Education and Culture, the regional government, other parties who can assist the implementation of the SLM.

\section{Science Literacy Inventory}

Scientific literacy assessment conducted by Science teacher or classroom teacher. The inventory results are listed in Table II.

\section{TABLE II. RESULTS OF SCIENCE LITERACY INVENTORY}

\begin{tabular}{|c|c|c|c|c|c|c|c|c|c|c|c|c|c|}
\hline \multirow{3}{*}{$\begin{array}{c}\text { Compon } \\
\text { ent }\end{array}$} & \multirow{3}{*}{$\mathbf{S}$} & \multicolumn{12}{|c|}{ Score } \\
\hline & & \multicolumn{3}{|c|}{ MJK } & \multicolumn{3}{|c|}{ GRS } & \multicolumn{3}{|c|}{ PDN } & \multicolumn{3}{|c|}{ GDG } \\
\hline & & $E$ & $\boldsymbol{J}$ & $S$ & $E$ & $J$ & $S$ & $E$ & $\boldsymbol{J}$ & $S$ & $E$ & $J$ & $S$ \\
\hline \multirow{4}{*}{$\begin{array}{l}\text { 1. Base } \\
\text { on } \\
\text { Class }\end{array}$} & A & 0 & 0 & 0 & 0 & 0 & 0 & 4 & 4 & 4 & 2 & 2 & 2 \\
\hline & B & 3 & 3 & 3 & 3 & 3 & 3 & 4 & 4 & 4 & 1 & 1 & 1 \\
\hline & $\mathrm{C}$ & 2 & 3 & 2 & 2 & 2 & 2 & 2 & 2 & 2 & 1 & 1 & 1 \\
\hline & $\mathrm{D}$ & 3 & 3 & 3 & 1 & 2 & 2 & 2 & 2 & 2 & 1 & 1 & 1 \\
\hline \multirow{6}{*}{$\begin{array}{l}\text { 2. Base } \\
\text { on } \\
\text { School } \\
\text { Culture }\end{array}$} & A & 2 & 2 & 2 & 3 & 3 & 3 & 4 & 4 & 4 & 1 & 1 & 1 \\
\hline & B & 2 & 2 & 2 & 2 & 2 & 2 & 3 & 3 & 3 & 1 & 1 & 1 \\
\hline & $\mathrm{C}$ & 3 & 3 & 3 & 2 & 2 & 2 & 2 & 2 & 2 & 1 & 1 & 1 \\
\hline & $\mathrm{D}$ & 0 & 0 & 0 & 1 & 1 & 1 & 1 & 1 & 1 & 1 & 1 & 1 \\
\hline & E & 0 & 0 & 0 & 0 & 0 & 0 & 0 & 0 & 0 & 1 & 1 & 1 \\
\hline & $\mathrm{F}$ & 2 & 2 & 2 & 1 & 1 & 1 & 2 & 2 & 2 & 1 & 1 & 1 \\
\hline \multirow{3}{*}{$\begin{array}{l}\text { 3. Base } \\
\text { on } \\
\text { Society }\end{array}$} & A & 3 & 3 & 3 & 1 & 1 & 1 & 2 & 2 & 2 & 1 & 1 & 1 \\
\hline & $\mathrm{B}$ & 1 & 1 & 1 & 1 & 1 & 1 & 1 & 1 & 1 & 1 & 1 & 1 \\
\hline & $\mathrm{C}$ & 1 & 1 & 1 & 1 & 1 & 1 & 1 & 1 & 1 & 2 & 2 & 2 \\
\hline
\end{tabular}

Table II show that there are 2 school MJK and GRS got the lowest value on 1A component. There are 3 school MJK, GRS, and PDN got the lowest value on 2E component. Almost all components for GDG got 1 (one) value.

\section{Science Matter Inventory}

Science matter inventory conducted by science teacher or classroom teacher.

TABLE III. RESULTS OF SCIENCE MATTER INVENTORY

\begin{tabular}{|l|l|c|c|c|c|}
\hline \multirow{3}{*}{ Component } & \multirow{2}{*}{ SI } & \multicolumn{4}{|c|}{ Score } \\
\cline { 3 - 6 } & & MJK & GRS & PDN & GDG \\
\hline 1. Science & $\mathrm{A}$ & 3 & 3 & 4 & 1 \\
\cline { 2 - 6 } & $\mathrm{B}$ & 3 & 3 & 4 & 1 \\
\cline { 2 - 6 } & $\mathrm{C}$ & 3 & 1 & 4 & 1 \\
\cline { 2 - 6 } & $\mathrm{D}$ & 2 & 1 & 4 & 1 \\
\hline \multirow{4}{*}{$\begin{array}{l}\text { 2. Learning } \\
\text { Process }\end{array}$} & $\mathrm{A}$ & 3 & 2 & 2 & 1 \\
\cline { 2 - 6 } & $\mathrm{B}$ & 2 & 1 & 3 & 1 \\
\cline { 2 - 6 } & $\mathrm{C}$ & 1 & 2 & 3 & 1 \\
\cline { 2 - 6 } & $\mathrm{D}$ & 2 & 2 & 2 & 1 \\
\cline { 2 - 6 } & $\mathrm{E}$ & 3 & 4 & 3 & 1 \\
\cline { 2 - 6 } & $\mathrm{F}$ & 3 & 3 & 3 & 1 \\
\cline { 2 - 6 } & $\mathrm{G}$ & 3 & 2 & 4 & 1 \\
\cline { 2 - 6 } & $\mathrm{H}$ & 3 & 2 & 4 & 1 \\
\cline { 2 - 6 } & $\mathrm{I}$ & 3 & 4 & 4 & 1 \\
\cline { 2 - 6 } & $\mathrm{J}$ & 3 & 4 & 4 & 1 \\
\cline { 2 - 6 } & $\mathrm{K}$ & 3 & 4 & 4 & 1 \\
\cline { 2 - 6 } & $\mathrm{L}$ & 3 & 2 & 4 & 1 \\
\cline { 2 - 6 } & $\mathrm{M}$ & 2 & 2 & 3 & 1 \\
\hline \multirow{4}{*}{ Utility and } & $\mathrm{A}$ & 3 & 1 & 4 & 1 \\
\hline \multirow{4}{*}{} & & & &
\end{tabular}

\begin{tabular}{|l|l|c|c|c|c|}
\hline \multirow{3}{*}{ Component } & \multirow{2}{*}{ SI } & \multicolumn{4}{|c|}{ Score } \\
\cline { 2 - 6 } & & $\boldsymbol{M J K}$ & $\boldsymbol{G R S}$ & $\boldsymbol{P D N}$ & $\boldsymbol{G D G}$ \\
\cline { 2 - 6 } Infrastructure & $\mathrm{B}$ & 0 & 1 & 2 & 1 \\
\cline { 2 - 6 } & $\mathrm{C}$ & 0 & 1 & 1 & 1 \\
\hline 4. Learning & $\mathrm{A}$ & 3 & 2 & 4 & 1 \\
\cline { 2 - 6 } Source & $\mathrm{B}$ & 1 & 2 & 2 & 1 \\
\cline { 2 - 6 } & $\mathrm{C}$ & 0 & 1 & 1 & 1 \\
\cline { 2 - 6 } & $\mathrm{D}$ & 1 & 1 & 4 & 1 \\
\hline
\end{tabular}

Table III shown that each component science matter in GDG got same value 1 (one). There are several component in $\mathrm{MJK}$ got the lowest value, 3B, 3C, and $4 \mathrm{C}$.

\section{B. Discussion}

This research is a preliminary data collection to determine the implementation of SLM, scientific literacy, and science matter. The instrument used was in the form of an assessment sheet which was divided into three parts, namely the SLM assessment sheet, scientific literacy, and science matter. This research is devoted to school for dissabilities Subject of this study are 4 different school for dissabilitiess namely Pertiwi Mojokerto school for dissabilities, Kemala Bhayangkari 2 Gresik school for dissabilities, State School for dissabilities of Pandaan, and State School for dissabilities of Gedangan.

SLM assessment is carried out by the internal school, namely the headmaster. There are 9 components of SLM assessment, namely initial assessment, SLM socialization, SLM policy design, SLM activity design, development of learning-based SLM, development of school culture-based NLM, development of community-based SLM, implementation of six dimensions of literacy, and evaluation of SLM. This component complies with the Ministry of Education and Culture's NLM evaluation evaluation guidelines. Each component has different success indicators. Each indicator has an assessment criterion of $0-4$. The assessment is carried out for education levels ESD, JHSD, and SHSD [9].

The initial assessment component has 4 success indicators. These indicators are A. Learning resources, utilities and infrastructure in schools. B. Human resources, utilities and infrastructure outside of school. C. Human resources who understand SLM. D. Potential of school culture. This initial assessment is used to see the input held both inside and outside the school to implement SLM [1].

There are 6 components that can be used to assess the school process in implementing SLM. These components are SLM socialization, SLM policy design, SLM activity design, learning-based SLM development, school culturebased NLM development, community-based SLM development, and implementation of six literacy dimensions. The SLM socialization component consists of 2 
success indicators, namely A. SLM socialization, and B. Formulation of priority activities [9].

The SLM policy design component has 2 success indicators namely A. the SLM implementing team, and B. the school regulations that support SLM. Components The design of SLM activities has 5 success indicators. The indicator A. SLM activities correspond to six dimensions of literacy. B. Use of environmental potential. C. flagship activities integrated six literacy dimensions. D. excellent activities with three bases. E. Literacy activities and social activities [9].

The next component is the development of class-based SLM. This component has 4 success indicators namely A. integrated literacy activities in RPP, B. contextual learning material, C. relevant learning methods, and D. teacher capacity in learning. The school culture-based NLM development component has 10 success indicators. These success indicators are related to school culture and the six dimensions of literacy [9].

The community-based SLM development component has 5 success indicators. A. Parental capacity, B. Active role of the community, C. Utilization of learning resources outside of school, D. Community contributions, and D. Criticism and suggestions from the community. The next component is the implementation of six dimensions of literacy. This component consists of 6 success indicators. These indicators relate to the 6 dimensions of literacy, namely literacy, numeracy, science, digital, finance, culture and citizenship [9].

The last component is SLM evaluation. This component consists of 7 success indicators. A. SLM instruments, B. Routine monitoring, C. feedback on SLM implementation, D. use of utility and infrastructure, E. academic achievement, F. Obstacles, G. suggestions, efforts or solutions [9]. This component is used to determine the output of SLM implementation [1].

The nine components correspond to the stages of the literacy movement in school for dissabilities. These stages are the preparation of work programs, institutional capacity building and socialization of human resources, and involvement of public participation. The implementation of SLM in school for dissabilities is also adjusted to the obstacles students have, which can develop language skills. These skills include listening, speaking, reading and writing skills [5].

Based on Table I it can be seen that there are differences in the implementation of SLM in 4 school for dissabilities. In the MJK school, there are several unsuccessful success indicators with the lowest score of 0 , namely $3 \mathrm{~A}, 8 \mathrm{D}, 9 \mathrm{~A}$, and 9C. Success indicators $3 \mathrm{~A}$ shows that MJK has not yet had a SLM implementation team. 8D's success indicators show that MJK does not yet have reading material and activities that develop digital literacy. 9A's success indicators indicate that MJK does not yet have an instrument to measure the success of SLM, while 9C shows that there is no feedback on the implementation of SLM in MJK.

Success indicators that get a maximum score of 4 in MJK are 1A regarding learning resources, utility and infrastructure in schools for ESD levels, while for JHSD and SHSD get a score of 3 . Other components get a score of 1,2 and 3 at each level of education according to the data in the Table I. These results indicate that SLM has been implemented at MJK even though it has not been successful.

The Obstacles that occur in the MJK have not been written down, so it is unknown what causes the implementation of SLM not to the maximum. MJK requires facilities that can support the implementation of SLM. In addition, there is a need for socialization and education and training for school residents and the community. SLM program standards are needed and evaluations are conducted regularly.

In GRS schools there are several success indicators that get a minimum score of 0 , namely $3 \mathrm{~A}, 8 \mathrm{~B}$, and $9 \mathrm{~A}$. Success indicators $3 \mathrm{~A}$ shows that GRS has not yet had a SLM implementation team. Success indicators $8 \mathrm{~B}$ shows that GRS does not have reading material and activities that develop numeracy literacy. Success indicators 9A shows that GRS does not yet have an instrument to measure SLM success.

GRS obtained a maximum score of 4 more than the MJK. The success indicators are $1 \mathrm{C}$ (human resources who understand SLM), 4B (environmental potential), 4E (literacy activities and social activities), 5B (contextual learning material), 5D (teacher capacity building). In addition, success indicators are 6D (cultural literacy attitude), 6E (attitude in numeracy literacy), 6G (attitude in scientific literacy), $6 \mathrm{~J}$ (attitude in cultural titration and citizenship), 7A (parental capacity), 7B (active role of the community), 7C (learning resources outside of school), 7E (advice, criticism from the community).

Other components get a score of 1,2 and 3 at each level of education according to the data in Table I. These results indicate that SLM has been implemented at GRS even though it has not been maximized. Obstacles that occur in GRS are the ability of students to interpret sentences, and the facilities needed for some SLM components. Based on the advice given, GRS requires learning resources that are appropriate to the student's shortcomings. GRS also requires facilities that students can use to develop literacy skills.

PDN, based on Table I only gets 1 success indicators that get a minimum score of 0 , namely $6 \mathrm{C}$ (community literacy to improve literacy school culture). This shows that almost all SLM components have been implemented. There is one success indicator that scores 1, 7A (the capacity of parents in supporting SLM implementation). Other components scored 2, 3, and 4. These results indicate that 
the implementation of SLM in PDN is better than the previous 2 schools namely MJK and GRS.

Obstacles in implementing SLM in PDN are the limited ability of students. Based on the advice given, PDN requires additional learning resources to support literacy. PDN requires workshops to improve the quality of literacy schools. It also needs to be an active role of school, community, DUDI, and government citizens to support SLM.

Table I shows the SLM score on the GDG there is no minimum score of 0 in all components. These results indicate that all SLM components in GDG are implemented. The minimum score obtained is 1 , for $7 \mathrm{D}$ success indicators (community contributions), 8B (reading material and activities that develop literacy), 9A (SLM success instrument), and 9C (SLM implementation feedback). There is no maximum score of 4 on GDG. Other success indicators get a score of 2 and 3 .

These results indicate that the SLM at GDG has been implemented, although it has not been maximized. The scores obtained are equally for each component. Table II shows the obstacles in GDG, namely the absence of cooperation with the environment and society. The advice given, GDG requires SLM training. Utility and infrastructure support both from the government and CSR.

Based on this description, SLM in 4 schools has been implemented. Each school has advantages and disadvantages in implementing SLM. There are still many components that must be met in implementing SLM, such as utility and infrastructure, human resources, and community participation.

Scientific literacy assessment is carried out by the internal school, namely Science teacher or classroom teacher. There are 3 components of scientific literacy assessment, namely class base, school culture base, and community base. This component is adjusted with scientific literacy indicators in schools [11]. Each component has different success indicators. Each indicator has an assessment criterion of $0-4$. The assessment is carried out for elementary, junior and senior high school education.

In the base component class there are 4 success indicators. A. teacher training, B. utilization of scientific literacy in learning, C. problem-based science learning and projects, D. products produced by students through learning [11]. This component is used to determine the learning process in class and the output produced by students during learning. This component can also be used to strengthen the capacity of facilitators such as teachers in supporting scientific literacy.

The basic component of school culture consists of 6 success indicators. These indicators are A. variation of reading material, B. frequency of borrowing reading material, C. scientific literacy activities, D. online site access, and E. presentation of scientific literacy information [11]. This component is important because it can demonstrate the use and access of quality learning resources that can support scientific literacy in schools.

The last component is the community base. In this component there are 3 success indicators. A. utility and infrastructure, B. parent involvement, and C. community involvement. This component is needed to determine the availability of supporting utilities and infrastructure, as well as public involvement such as parents and the community in supporting scientific literacy.

Table II shows the scientific literacy inventory scores in 4 schools. MJK gets a minimum score of 0 on success indicators 1A (teacher training), 2D (online site access), and 2E (team literacy). These results indicate that scientific literacy activities at MJK have not yet been carried out. There are no success indicators that get a maximum score of 4. It means, even though it has already been carried out, the scientific literacy activities are not yet optimal.

GRS gets a literacy score of at least 0 on aspects $1 \mathrm{~A}$ and 2E. This shows, in GRS there is no training for teachers, and there is no scientific literacy team in schools. Based on Table II, scientific literacy at GRS has been implemented, but it has not been maximized. The implementation of scientific literacy at GRS is almost the same as MJK, there are still indicators of success that have not been implemented, and there are no success indicators that get a maximum score of 4 .

The results of scientific literacy inventory in PDN shows that there are still 1 success indicators that have not been implemented, namely $2 \mathrm{E}$ (scientific literacy team). Success indicators that get a maximum value of 4 are $1 \mathrm{~A}, 1 \mathrm{~B}$, and 2A. That is, the implementation of maximum scientific literacy for teacher training, the use and application of scientific literacy in learning, as well as variations in scientific literacy reading materials. Scientific literacy activities in PDN have been implemented quite well, although there are still 1 success indicators that have not been implemented. The implementation of scientific literacy in PDN is better than MJK and GRS.

The maximum score for implementing scientific literacy in GDG is 2, for success indicators $1 \mathrm{~A}$ (teacher training) and 3C (community involvement in scientific literacy). Minimum score of 1 for all success indicators except 1A, and $3 \mathrm{C}$. These results indicate that all scientific literacy components are implemented but not maximized. The implementation of scientific literacy in GDG is no better than PDN.

Based on the description above, it can be seen if scientific literacy has been carried out in each school, but it has not been maximized. There are still deficiencies in several ways, namely teacher training and team literacy. In addition, scientific literacy support facilities are also 
inadequate for ESD. To achieve quality improvements in scientific literacy, it is crucial for teachers to develop their own positive attitude toward science [3].

Scientific literacy can be improved by appropriate learning processes, such as problem-based learning [12]. Scientific literacy can also be increased with appropriate learning activities [13]. The development of scientific literacy can contribute to social and economic life, and to improve personal level [14].

Science matter assessment is carried out by internal school, namely Science teacher or classroom teacher. There are 4 components of assessment namely science matter, teaching and learning process, utility and infrastructure, and learning resources. These components are adapted to natural science learning in the hearing impairment ESD. Each component has success indicators with score criteria 0 - 4 .

First, the science matter component which has 4 assessment indicators. The assessment indicators are about themes and sub themes in ESD, as well as the relationship between themes and sub themes with science matter and chemistry in everyday life. This component is used to find out about science learning in ESD.

Second, the components of the learning process. This component has 13 assessment indicators. This assessment indicators regarding the learning process carried out at ESD. Contextual learning, relevant learning methods, use of instructional media, and linking learning with daily life. This component is used to determine the learning of science in ESD carried out contextually.

Third, component utility and infrastructure. There are 3 assessment indicators, which include utility and infrastructure inside and outside of school, as well as access to online sites. This component is used to determine the availability and utilization of utilities and infrastructure that support science learning.

Fourth, component learning resources. Consists of 4 assessment indicators, namely, the use of textbooks, learning resources, human resources, and non-textbooks. This component is used to determine the availability and utilization of learning resources supporting science matter in schools.

Table III shows the results of the science matter inventory of 4 schools. There are several assessment indicators that have not yet been fulfilled at MJK. The assessment indicators are 3B (online site access), 3C (utility and infrastructure outside of school), and 4C (human resources outside of school). There are no assessment indicators that get a maximum score of 4 . This shows that there is still a component of science matter in MJK.

The minimum score for science matter for GRS is 1 , for assessment indicators 1C (contextual sub themes), 1D (contextual science matter), 2B (learning methods), 3A (utility and infrastructure in schools), 3B (online site access), 3C (utility and infrastructure outside of school), 4C (human resources outside of school), 4D (non-learning books). Indicators that get a maximum score of 4 are $2 \mathrm{E}$ (bathroom chemicals), 2I (food ingredients), 2J (household appliance materials), $2 \mathrm{~K}$ (science learning support activities). These results indicate that science matter in GRS has all been carried out, although there are assessment indicators that have not been maximized.

PDN gets a minimum score of 1 in the $3 \mathrm{C}$ assessment indicators (utility and infrastructure outside of school), and 4C (human resources outside of school). More assessment indicators have a maximum score of 4 than GRS. This shows that the component of science matter in PDN has been fulfilled quite well.

GDG gets a maximum score of 1 for all assessment indicators. This shows that in GDG all the components of science matter are met but not yet maximized. Science matter in GDG is no better than MJK and GRS.

Based on this description, science matter taught at ESD in every school is still not optimal. There are a number of assessment indicators that have not yet been fulfilled, for example online site access, utilities and infrastructure outside of school, lack of contextual learning of science, and human resources outside of school

Special education needs adapting to the individual peculiarities and characteristics of a certain learning deficiencies. That is why teacher need technique and method to optimizing the educational process [15]. Teacher leadership practice must be adapted to school for dissabilities teachers in order to create quality and effective classroom management practice [16]. Students in school for dissabilities needs right instructional media to increase study of science especially for hearing impairment students [6][7][8][9].

\section{IV.CONCLUSION}

Based on the results of the inventory it can be concluded that 4 schools have implemented SLM, scientific literacy and science matter. There are components in SLM and scientific literacy that have not been implemented. There is a component of science matter assessment in each school that still gets a minimum grade, so it needs to be improved with making science multimedia design for scientific literacy activity as supporting SLM. The implementation of SLM, scientific literacy and science matter needs active roles from various parties too for completed the utilities in scientific literacy activity in school for dissabilities hearing impairment.

\section{ACKNOWLEDGEMENT}

Thanks to Universitas Negeri Surabaya, for providing the opportunity to conduct research with Non-Tax State Revenue (PNBP) funds. Thank you very much to State 
School for dissabilities of Gedangan, State School for dissabilities of Pandaan, Kemala Bhayangkari 2 Gresik school for dissabilities, and Pertiwi Mojokerto school for dissabilities for supported observation and assessment.

\section{REFERENCES}

[1] Tim GLN Kemendikbud, "Panduan GLN," Jakarta: Kemendikbud, 2017.

[2] Purbaningrum, Y, "Model Scaffolding Pembelajaran Menulis dengan Pendekatan Proses Bagi Anak Tunarungu," Surabaya: PGPLB UNESA, Nomor 2, 2013.

[3] Dragos, V. and Mih, V, "Scientific Literacy in School," ProcediaSocial and Behavioral Science, Vol. 209, p. 167-172, 2015.

[4] Poedjiastoeti, S, "Pembelajaran Kimia untuk Siswa Tunarungu," Prod.Prosiding xv. A1-A15, 2010.

[5] Wahyuningsih, S., Yusuf, A., Rismayati, R., and Setiakarnawijaya, Y., "Panduan Gerakan Literasi Sekolah di SLB," Jakarta: Dirjen Dikdasmen, 2016.

[6] Poedjiastoeti, S., Novita D., Miseri, "Recognation of Chemistry Laboratory Equipment to Increase Study Science in Senior High School for Special Education (Hearing impairment)" Proceeding of the First International Seminar of Science Education. ISBN: 979-250599-7, 2007.

[7] Poedjiastoeti, S., and Liliasari, "Pembelajaran Kimia Berbantuan Multimedia untuk Siswa Tunarungu SMALB-B," Jurnal Ilmu Pendidikan, Volume 17, Number 1, p. 55-63 (available at: https://www.neliti.com/id/journals/jurnal-ilmu-pendidikanuniversitas-negeri-malang), 2010.
[8] Poedjiastoeti, S., "Learning Mixture Topic Using Multimedia And Kit Chemistry For Hearing Impairment Students," Proceeding International Conference on Educational Research (ICER), p. 10291039, ISBN 978-616-223-123-0, 2011.

[9] Poedjiastoeti, S., "Kit Kimia dengan Strategi Writing-to-learn untuk Siswa SMALB Tunarungu," Prosiding Seminar Nasional Kimia Unesa 2012, p. B179-B188, 2012.

[10] Tim GLN Kemendikbud, "Pedoman penilaian evaluasi GLN" Jakarta: Kemendikbud, 2017

[11] Tim GLN Kemendikbud, "Materi Pendukung Literasi Sains," Jakarta: Kemendikbud, 2017

[12] Nurjanah, A., Sudin, A., Sujana, A., "Literasi Sains dalam Pembelajaran Berbasis Masalah," Jurnal Pena Ilmiah, Vol. 2, No. 1, p. 581-590, 2017.

[13] Genc, M., " The Effect of Science Studies on Students' Scientific Literacy and Attitude," Journal of Faculty Education, Vol. 34, No. 1, p 141-152, 2015 .

[14] Laugksch, " Scientific Literacy: A Conceptual Overview," South Africa: School of Educational University of Cape Town Private Bag. 7701, 2000.

[15] Barna, I, Dobrota, C., Dragu, M., " Optimising Special Education: Active Language and Psychomotor Education," Procedia- Social and Behavioral Science, Vol. 84, p. 390-395, 2013.

[16] Ngang, T. K., Abdullah, N. A. C., "Teacher Leadership and Classroom Management Practice on Special Education with Learning Disability," Procedia- Social and Behavioral Science, Vol. 205, p. 2-7, 2015. 